\title{
Neuroanatomy of Gryposuchus neogaeus (Crocodylia, Gavialoidea): a first integral description of the braincase and endocranial morphological variation in extinct and extant gavialoids
}

\author{
Paula Bona ${ }^{1, *}$, Ariana Paulina Carabajal ${ }^{2}$ and Zulma Gasparini ${ }^{1}$ \\ ${ }^{1}$ División Paleontología Vertebrados Museo de La Plata - Universidad Nacional de La Plata (UNLP), Consejo \\ Nacional de Investigaciones Científicas y Técnicas (CONICET), Paseo del Bosque S/N, 1900, La Plata, Argentina. \\ Email: paulabona26@gmail.com; zgaspari@fcnym.unlp.edu.ar \\ ${ }^{2}$ Instituto de Investigaciones en Biodiversidad y Medioambiente (INIBIOMA) - Universidad Nacional del \\ Comahue, Consejo Nacional de Investigaciones Científicas y Técnicas (CONICET), Quintral 1250 (R8400FRF), \\ San Carlos de Bariloche, Argentina.
}

Email: a.paulinacarabajal@conicet.gov.ar

*Corresponding author

\begin{abstract}
Morphological studies of the braincase and cranial endocast of fossil crocodylians, especially gavialids, are scarce. Here, we present a detailed description of the neuroanatomy of Gryposuchus neogaeus from the Miocene of Argentina, based on CT scans. The cranial endocast is sub-horizontal and the angle formed between the mid-brain and the hind-brain is poorly marked. When compared with Gavialis gangeticus, the mid-brain of G. neogaeus is relatively shorter, although the distribution of cranial nerves is similar. In the floor of the endocranial cavity, posterior to the dorsum sellae, there is a median foramen that leads into a canal that runs anteroventrally through the basisphenoid to penetrate the posterior wall of the pituitary fossa (open foramen for the basilar artery?). The same structure is present in G. gangeticus, but is absent in other living crocodylians, suggesting a potential synapomorphy of Gavialoidea. The pneumaticity of the skull roof and the lateral branches of the pharyngotympanic system in G. neogaeus are markedly reduced when compared with the extant species. Comparisons with the living Gavialis indicate that the pattern of braincase morphology of Gavialidae was present in the Miocene; however, the internal morphology, including brain shape, pneumaticity of the skull roof and basicranium, is different in the two species. This work is the first step to understand the variation of the neuroanatomy in this group of archosaurs and its palaeobiological implication.
\end{abstract}

KEY WORDS: cranial endocast, crocodylians, inner ear, Miocene, pneumaticity, palaeobiology, palaeoneurology, South America.

During the Miocene, South America was the scene of the diversification of most of the major Crocodylian (sensu Benton \& Clark 1988) clades and the most complete fossil records of South American crocodylians are derived from that time. Miocene South American Crocodylia show great morphological disparity, probably as a result of environmental diversity, mostly related with changes that occurred when the Western Amazonian wetland changed from a lacustrine system (Pebas System) to a fluvial or fluviotidal one (Acre System), associated with the Andean orogeny (Riff et al. 2010; Bona et al. 2013; Salas Gismondi et al. 2015).

The entire clade of gavialoids became extinct in South American and today they are represented by only one Asiatic species (Gavialis gangeticus). However, the late Miocene was the moment of South American lineage diversification. At least five described genera, including Gryposuchus Gürich, 1912, the most specious taxon of the group (Riff \& Aguilera 2008; Riff et al. 2010), are from the late Miocene. The medium-sized Gryposuchus neogaeus (Burmeister, 1885) is registered in North East Argentina from the Upper Miocene Ituzaingó Formation ("Conglomerado Osífero"; Paraná area; Fig. 1). Although the type material originally described by Burmeister (1885, p. 151; a rostral fragment) is lost, this species was redescribed by Gasparini (1968) on the basis of two specimens currently housed at the Museo de La Plata (MLP), corresponding to an isolated braincase (MLP 68-IX-V-1) and an articulate skull (MLP 26- 413).

Detailed anatomical descriptions of external and, especially, internal neurocranial morphology in Crocodyliformes are scarce (e.g., Witmer et al. 2008; Bona et al. 2013, and references therein; Bona \& Paulina Carabajal 2013). This is also true for extant gavialids, whose endocranial cavity is briefly described or illustrated in papers with different scopes (e.g., Gold 2011). Moreover, endocranial studies of fossil gavialids are even rarer and, so far, only the natural endocast of Thoracosaurus macrorhynchus Lemoine (1883) has been described (see Brochu (2004) for a taxonomic review of "thoracosaurids"). The braincase in particular is a complex structure formed by several bones and "molded" by several vital systems, such as the muscular, nervous and respiratory systems (Holliday \& Witmer 2004). Some aspects of those systems can be interpreted from the impressions left externally on the braincase (e.g., pneumatic 


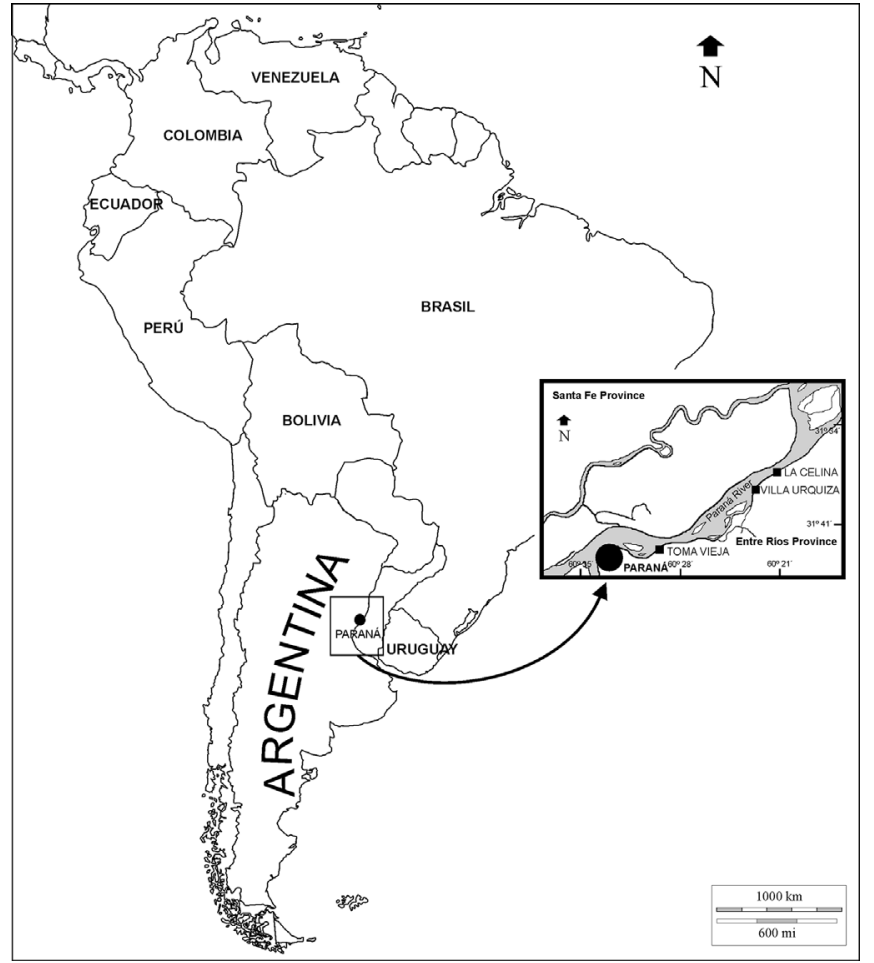

Figure 1 Geographic location map of the main outcrops of the "Conglomerado osífero" fossiliferous level, Ituzaingó Formation, Paraná area, Argentina. Modified from Brandoni \& Scillato-Yané (2007).

recesses, musculature attachment impressions). Furthermore, a closely-related field is that of palaeoneurology, which searches for the interpretation of sensorineural capabilities in extinct taxa (e.g., Jerison 1973; Hopson 1979). In reptiles, the brain itself does not fill the endocranial cavity, and thus the endocast is a cast of the dural envelope. However, the major neurovascular features, such as brain shape and the canals for the cranial nerves and blood vessels, can be recognised (e.g., Witmer et al. 2008 and references therein). Important palaeobiological inferences can be made based on brain size and structure, such as an intelligence measure using the encephalisation quotient (e.g., Jerison 1973; Hopson 1979); or hearing, balance, eye movement and head posture based on inner ear morphology (e.g., Witmer et al. 2008; Paulina Carabajal et al. 2014).

Here, we present a detailed description of the neuroanatomy of the extinct Gryposuchus neogaeus and the extant Gavialis, using CT scans. The main goal of this contribution is to describe for the first time in detail the external and internal neurocranial morphology of an extinct gavialoid, G. neogaeus. This is the first step in understanding the variation of the neuroanatomy in this lineage, in order to yield new evidence to explore its implication for the palaeobiology of the group.

Institutional abbreviations. AMU-CURS, Alcaldía del Municipio Urumaco, Venezuela; MCN, Museo de Ciencias Naturales, Caracas, Venezuela; MCT, Museu de Ciências da Terra, Rio de Janeiro, Brasil; MLP, Museo de La Plata, Argentina; UCMP, Museum of Paleontology, University of California, Berkeley, USA; UFRG, Universidade Federal de Rio de Janeiro; USNM, United States National Museum, Washington, DC, USA

\section{Material and methods}

The studied Gryposuchus neogaeus specimens MLP 26-413 and MLP 68-IX-V-1 (Figs 2, 3) are housed in the Museo de La Plata collections. The specimen MLP 26-413 (Gasparini 1968) (Fig. 2) corresponds to an articulated skull. However, the braincase area is crushed and fixed with glues and pieces of metal, and therefore it was not chosen for CT scanning. The specimen MPL 68-IX-V-1 corresponds to an isolated and fragmentary braincase, missing anteriorly large portions of the frontals and laterosphenoids (Fig. 3). The endocranial cavity was emptied of sediment, allowing first hand observation of the internal morphology.

CT scans of the braincases of MLP 68-IX-V-1and the extant Gavialis gangeticus (MLP 602) were performed at San Juan de Dios Hospital (La Plata, Argentina), using a General Electric medical tomographer. The slices were taken at $0.62 \mathrm{~mm}$ intervals, using bone filter (fossil: $\mathrm{kv}=120$ and $\mathrm{mA}=240$; extant: $\mathrm{kv}=120$ and $\mathrm{mA}=180$ ). Virtual three-dimensional inner ear and cranial endocasts were obtained using the software Mimics (version 18.0) and Geomagic. Latex endocasts for one extant adult, Caiman yacare (MLP 605), and one subadult, C. latirostris (MLP 601), were also used for comparison. Studied specimens of both extinct and extant gavialoids correspond to adult individuals. Comparisons with juvenile extant Gavialis were based on the descriptions made by Gold (2011). Material of extinct gavialoids, such as Gryposuchus sp. (MCT 1858-R) and G. colombianus (UCMP 38358) was studied first hand, whereas the holotypes of G. colombianus (UCMP 41136) and G. croizati (MCN-URU-2002-77; AMU-CURS-58) were examined from the literature (Langston 1965; Langston \& Gasparini 1997; Riff \& Aguilera 2008). Comparisons with other extant crocodylian endocasts were based on published descriptions of Caiman crocodilus (available information published at http://www.digimorph.org), Crocodylus siamensis (Kawabe et al. 2009), C. johnstoni (Witmer et al. 2008), C. moreletii (Franzosa 2004) and Alligator mississippiensis (Witmer \& Ridgely 2008; Kawabe et al. 2009).

\section{Description}

\subsection{Braincase}

The braincase of Gryposuchus neogaeus (MLP 68-IX-V-1) is partially preserved, with a large portion of the frontals and the laterosphenoids missing (Fig. 3). In dorsal view, the skull roof outline is strongly trapezoidal, being posteriorly wider. The ornamentation lacks the pits and cells, being reduced to striations and roughness as in other gavialoids (Figs 2, 3F). Both interfenestral and postfenestral spaces are reduced to slender bars, given the huge size of supratemporal fenestrae. In $G$. neogaeus, the postfenestral bar is greatly reduced to a slender lamina, instead of a narrow bar as in other gavialoids (Gasparini 1968), which is probably an autapomorphy of this species. Supratemporal fenestrae are markedly larger than orbits and infratemporal fenestrae, as in other Gryposuchus species (e.g., G. croizati, G. colombianus; Langston 1965, fig. 6; Riff \& Aguilera 2008, figs 2A, 3A). The supratemporal fenestra is subcircular (MLP 26-413; Fig 2), more elongated transversely and delimited by the parietal (posteromedially), frontal (anteriomedialy), postorbital (anterior-laterally) and squamosal (posterior-laterally). As in G. croizati, the postorbital did not contact the frontal (see Riff \& Aguilera 2008). As in other Gryposuchus species, the supratemporal fenestrae in dorsal view are as large as the supratemporal fossae. In G. neogaeus, the supratemporal fossae are deep, and delimited by vertical walls which bear shallow grooves in their anterior and posterolateral regions (Fig 2B). We interpret these grooves as vascular impressions of ramifications of the tempororbital vessels sensu Sedlmayr (2002, fig. 10B), which probably communicate with superficial blood sinuses. In other crocodylians, such as the caimanines Mourasuchus nativus (Bona et al. 2013), 


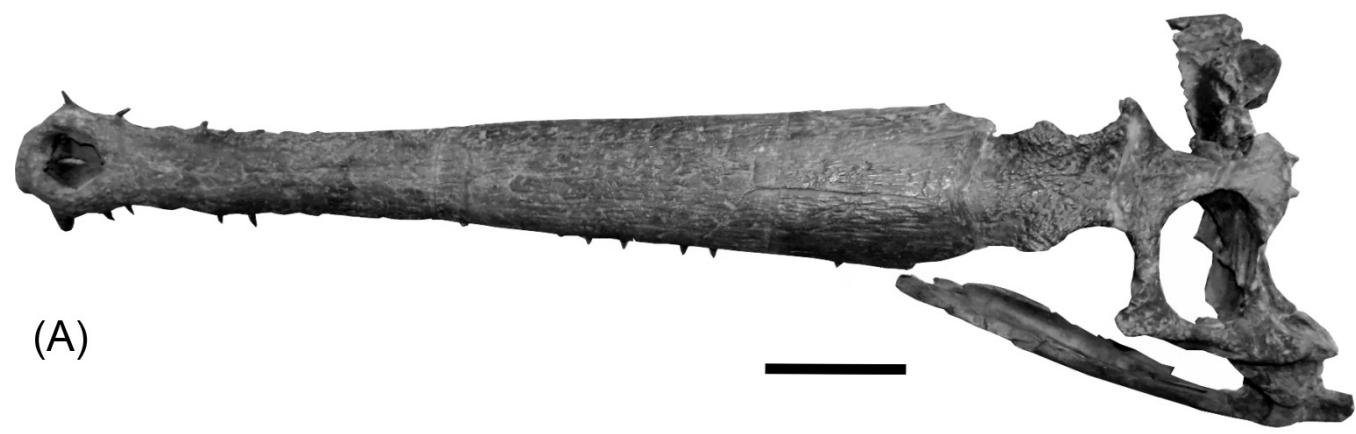

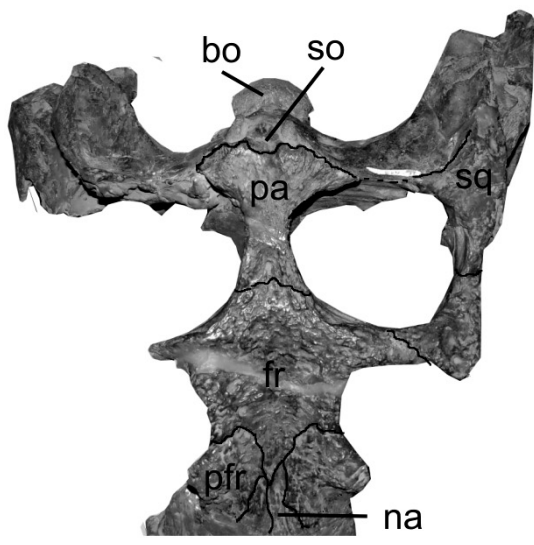

(B)

Figure 2 Gryposuchus neogaeus, MLP 26-413: (A) skull in dorsal view; (B) skull table in dorsal view; (C) skull in occipital view. Abbreviations: bo = basioccipital; eo = exoccipital; $\mathrm{fm}=$ foramen magnum; fr $=$ frontal; na $=$ nasal; $\mathrm{pa}=$ perietal; prf $=$ prefrontal; $\mathrm{q}=$ quadrate; $\mathrm{so}=$ supraoccipital; $\mathrm{sq}=$ squamosal. Scale bars $=$ $10 \mathrm{~cm}$.

and in extinct and extant Caiman (e.g., C. gasparinae, C. yacare and C. latirostris; Bona \& Paulina Carabajal 2013), anterolateral and posteromedial vascular grooves are present and located on the skull roof. The posteromedial groove was also reported in the crocodyliform Aegisuchus witmeri (Holliday \& Gardner 2012; see discussion below).

2.1.1. Frontal. The frontal is preserved in MLP 26-413 (Fig. 2A, B). Its dorsal surface is rough, although with no pits. The frontal contacts the parietal posteriorly, forming the anterior-medial margin of the orbits. The interorbital distance is larger than the orbit width, which is relatively larger than in $G$. colombianus, but smaller than in $G$. croizati. Although the anterior end of the frontal is difficult to distinguish in the holotype, it can be interpreted that the rostral process of frontal probably extends beyond the orbits slightly separating the nasals (Fig. 2B).

2.1.2. Parietal. As in other crocodiles the parietals are fused into a single element. The dorsal surface of the bone is flat and smooth, and forms a slender inter-fenestral bar. The parietal contacts the frontal anteriorly and the squamosals posterolaterally, forming the medial margin of supratemporal fenestrae. In Gryposuchus neogaeus, the posterior part of the parietal forms a wide 'tongue'-like surface projected over the supraoccipital (Figs 2B, 3F); in Gavialis gangeticus, the parietal is narrower posteriorly. As stated above, in Gryposuchus neogaeus, the post-fenestral bar is extremely reduced and the lateral expansions of the parietal taper laterally, contacting the opisthotic (posteroventrally) and the squamosal (laterally). At this point, the parietal is strongly compressed anteroposteriorly and the contact with the squamosals is greatly reduced. This feature contrast with the condition seen in G. colombianus and $G$ croizati (and even in other gavialoids, e.g., Eothoraco- saurus mississippiensis Brochu, 2004) in which the parietalsquamosal suture is longer and the anterior and posterior margins of the parietal at the post-fenestral bar are subparallel. In the same way, in Gavialis gangeticus, the parietal-squamosal contact is longer than in G. neogaeus, and the lateral expansion of the parietal forms a transversely projected tabular bar (Gold 2011, fig. 18). The posterior margin of the parietal presents a medial notch, so the ascending medial process of supraoccipital is exposed in dorsal view (Fig. 2A, B). A small notch is present in the posterior margin of the parietal of Gryposuchus sp. (MCT 1858-R) and G. colombianus (UCMP 38358; Langston 1965).

2.1.3. Supraoccipital. The supraoccipital is a vertical and triangular element on the occiput (Fig. 2B, C). It has an oblique dorsal and medial process that extends dorsoanteriorly and contacts the skull roof at the parietal notch (Fig. 2B, C). The contact with the otoccipital is a clearly visible interdigitated suture and, together, they delimit the post-temporal fenestrae ventrally, for the passage of vessels that stem from the orbitotemporal artery and vein (Sedlmayr 2002). The supraoccipital does not participate on the skull roof, but its medial oblique process is partially observed in dorsal view, among the posterior notch of parietal (Figs 2B, C, 3A, F). As in Gryposuchus sp. (MCT 1858-R), the supraoccipital knob is well developed, forming a small and short ridge ventrally and two large paired protuberances dorsally. At the distal end of the supraoccipital, these two protuberances form posteriorly projected horns. These protuberances are for the attachment of neck muscles (Cleuren \& De Vree 2000), and they are relatively larger than in Gavialis and in the Gryposuchus species $G$. colombianus and $G$ croizati. The supraoccipital is excluded from the dorsal margin of the foramen magnum by the exoccipitals, as in other Crocodylia. 


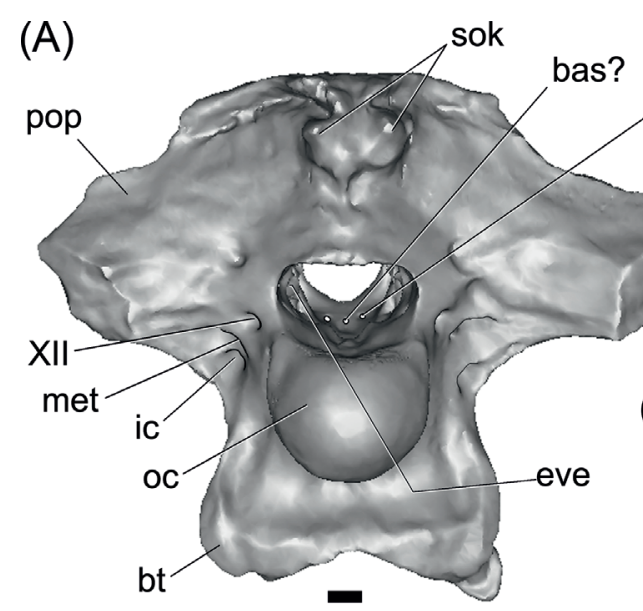

(D)

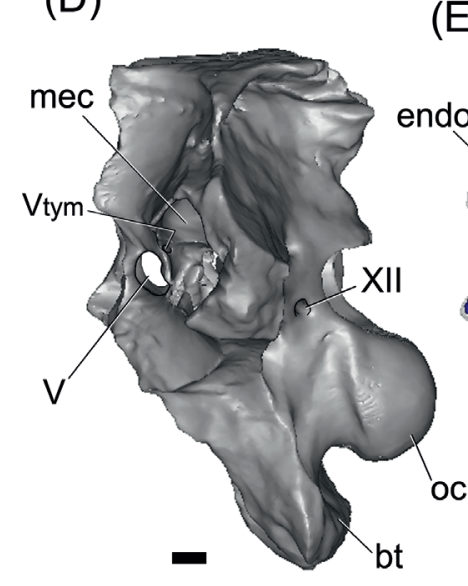

(E)

(B)

(C)

(C) $>\mathrm{fm}$

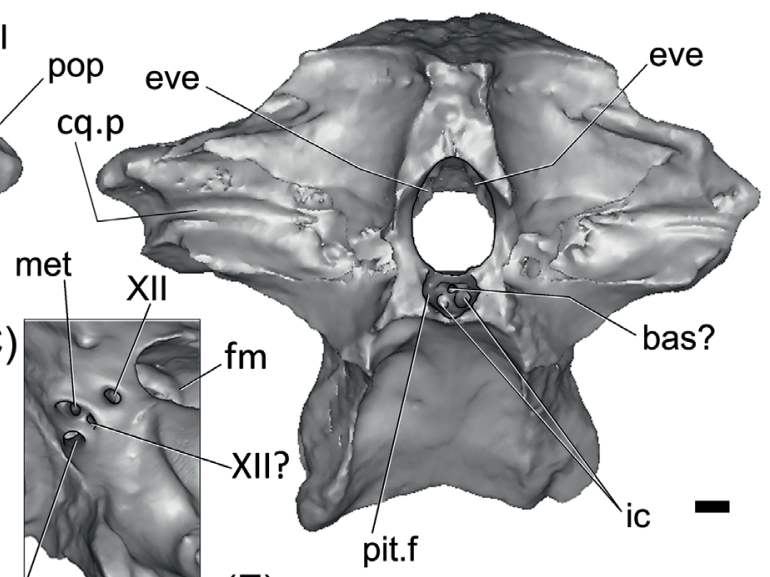

(F)

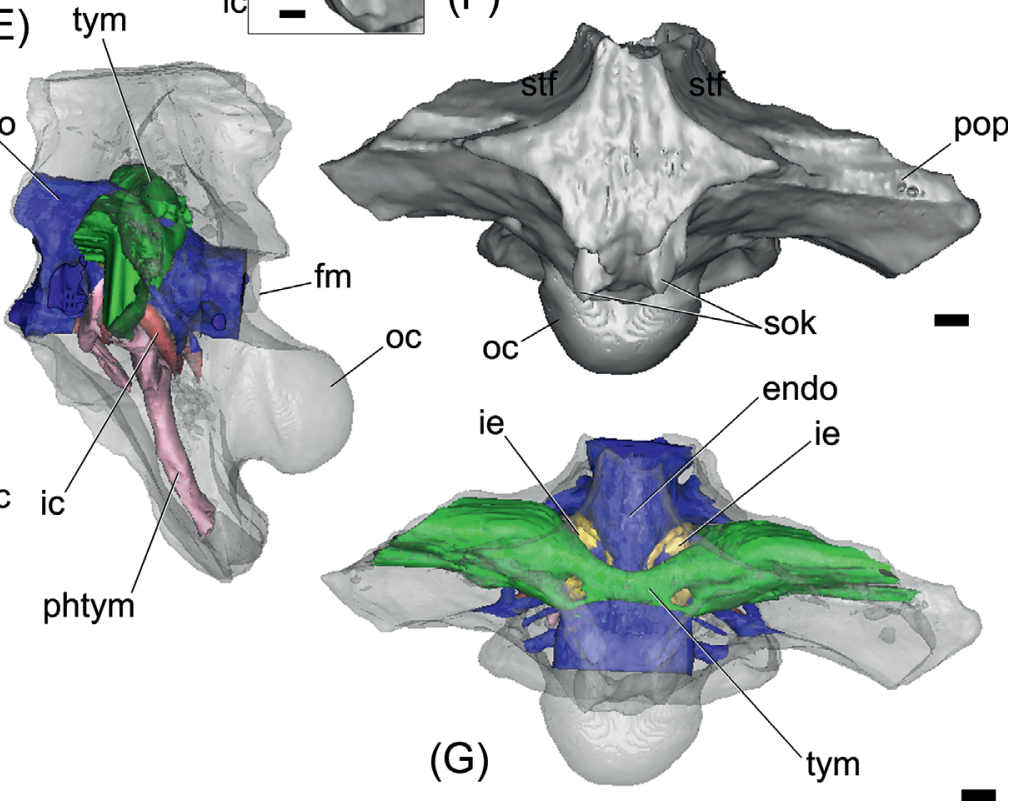

Figure 3 Gryposuchus neogaeus, MPL 68-IX-V-1: digital braincase and cranial endocast in posterior (A), anterior $(B)$, left lateral $(\mathrm{D}, \mathrm{E})$ and dorsal $(\mathrm{F}, \mathrm{G})$ views. Figure $(\mathrm{C})$ is a detail of cranial foramina lateral to the occipital condyle. The bone is rendered semitransparent in (D, E) to allow the view of the brain and pneumatic cavities $(\mathrm{E}, \mathrm{G})$. Abbreviations: bas? = basilar artery; bt $=$ basal tuber; cq.p $=$ cranioquadrate passage; endo $=$ cranial endocast; eve = vestibular eminence (unossified); $\mathrm{fm}=$ foramen magnum; ic = internal carotid foramen; $\mathrm{ie}=$ inner ear; $\mathrm{mec}=$ middle ear cavity; met = metotic foramen for CN IX-XI; oc = occipital condyle; phtym $=$ pharyngotympanic pneumatic recess; pit.f $=$ pituitary fossa; pop $=$ paroccipital process; sok $=$ supraoccipital knob; $\mathrm{stf}=$ supratemporal fossa; tym = paratympanic recess; $\mathrm{V}_{\mathrm{tym}}=$ tympanic branch of $\mathrm{CN} \mathrm{V}$ that enters the middle ear cavity; V, VI, XII = cranial nerves $(\mathrm{CN})$. Scale bars $=10 \mathrm{~mm}$.

2.1.4. Exoccipital-opisthotic complex. The exoccipitalopisthotic forms the lateral margins of the foramen magnum and the robust and slightly posteroventrally-projected paroccipital processes. In MLP 68-IX-V-1 (Figs 2C, 3A), both paroccipital processes are broken, lacking the distal ends (including the section in which the cranioquadrate foramen is located) and showing solid structures internally (the latter confirmed with the CT scans). The cranioquadrate passage is observed anteriorly on the quadrate, due to fractures, as a groove running horizontally between the opisthotic and the quadrate (the dorsal enclosure of the passage is made by the squamosal) (Figs 2C, 3B). The foramen magnum is wider than it is tall. Both exoccipitals join dorsally to the foramen magnum, excluding the supraoccipital from its dorsal margin and forming a slightly engrossed and posteriorly projected 'shelf' over the foramen, as in Gavialis gangeticus. The area of attachment of the muscle depressor mandibulae is deeply marked (Fig. 2C).

The crista tuberalis (or ventral ramus of the opisthotic), is deep, forming a large lamina of bone from the ventral border of the paroccipital process to the basal tubera. This lamina bounds the anterior margin of the foramen for the internal carotid artery and is not projected laterally. In the extant Gavialis gangeticus, the lateral margin of the ventral ramus of the opisthotic is relatively wider and forms a triangular surface laterally oriented. The basal tubera are more robust in $G$. gangeticus than in Gryposuchus neogaeus (Fig. 4).

Lateral to the occipital condyle, there are four cranial foramina: three correspond to the posterior cranial nerves and the fourth and more ventral is for the internal carotid artery (Figs $3 \mathrm{~A}, \mathrm{C}, 4 \mathrm{~B})$. The most posterior of these foramina corresponds to the cranial nerve $(\mathrm{CN}) \mathrm{XII}$. Anteroventral to it a small foramen for a possible separate branch of $\mathrm{CN}$ XII? and the metotic foramen (for CNs IX-XI), open within an oval and shallow recess delimited by the crista tuberalis (opisthotic) anteriorly and by the exoccipital posteriorly. On the endocast of Gryposuchus, the passage labelled as CN XII? is clearly separate from the CN XII and from the common root for CNs IX-XI, suggesting that it may correspond to a separate $\mathrm{CN} \mathrm{XI}$, or to a separate 
met

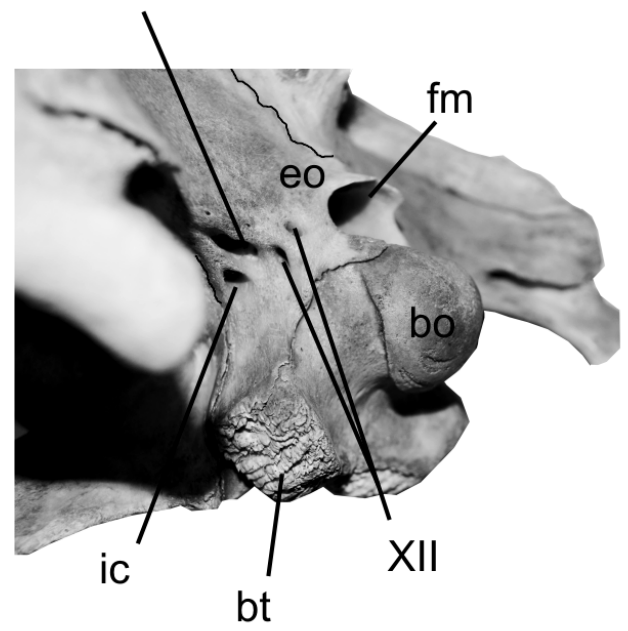

(A)

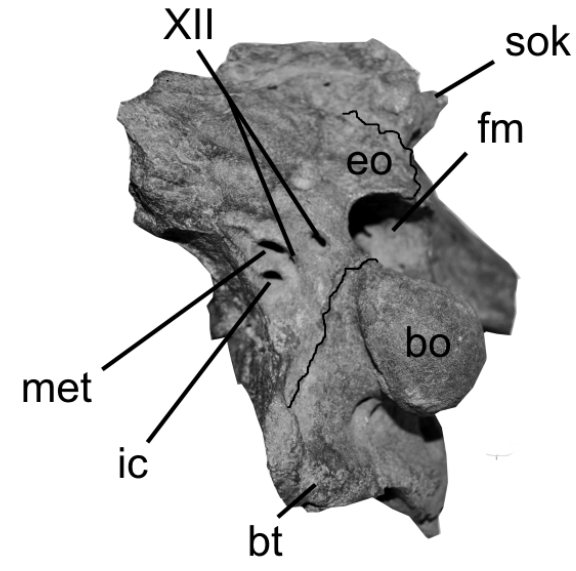

(B)

Figure 4 Braincases in posterolateral view: (A) Gavialis gangeticus, MLP 602; (B) Gryposuchus neogaeus, MLP 68-IX-V-1. Abbreviations: bo = basioccipital; bt = basal tuber; eo = exoccipital; fm = foramen magnum; ic = internal carotid foramen; met $=$ metotic foramen for CN IX-XI; sok = supraoccipital knob; XII = cranial nerve $(\mathrm{CN})$. Scale bar $=10 \mathrm{~cm}$.

and more rostral branch of CN XII. In Gavialis gangeticus, the same separate passage is observed, distally joined to the metotic passage and exiting the braincase through the same foramen. Knoll et al. (2015) considered (more conservatively) the presence of a second hypoglossal nerve over a separate root for CN XI in sauropod dinosaurs. Therefore, we identify this passage as a separate CN XII?, although the possibility that it belongs to a separate CN XI cannot be discounted.

2.1.5. Basioccipital and basisphenoid. The occipital condyle is formed mainly by the basioccipital, with small laterodorsal participation of the exoccipitals on the short occipital condyle neck. In the extant Gavialis, the neck of the condyle is relatively longer and the participation of the exoccipitals is larger (Fig. 4). In Gryposuchus neogaeus, the occipital condyle is subcircular in posterior view, with a flat dorsal margin. The neck of the condyle is constricted, rounded ventrally and bears a pair of small ventral vascular foramina. Ventral to the occipital condyle, the basal tubera are divergent but fused, forming a sub-triangular plate below the condyle. The ventral margin of this plate is slightly concave ventrally. The basioccipitalbasisphenoid suture is not visible in occipital view. In ventral view, the basioccipital and basisphenoid are strongly compressed anteroposteriorly. A large oval recess (transversely elongate) is delimited between both bones and, inside, it opens the foramen for the median Eustachian tube. A similar recess is observed in $G$. gangeticus, but this is relatively reduced. In an anterior view, the basisphenoid forms a vertical wall which delimits the dorsal walls of the pituitary fossa. In general terms, the basicranium (the floor of the endocranial cavity) is markedly anteroposteriorly short. In extant Gavialis, the basioccipital (distal end of the basal tubera) is more anteroposteriorly projected, forming a larger ventral surface than in Gryposuchus neogaeus (Fig. 4).

2.1.6. Prootic and laterosphenoid. On both lateral walls of the braincase, fragmentary prootics and laterosphenoids are preserved. Both laterosphenoids are incomplete in MLP 73IV-15-1, although in ventral view it can be observed that each laterosphenoid forms the anterolateral wall of the braincase and extends dorsally, forming the anteroventral area of the medial wall of the supratemporal fossa. On the left side, most of the laterosphenoid body (Holliday \& Witmer 2009) is pre- served. It is Y-shaped, with a slightly concave rostral margin (Fig. 3D) and the robust anterior ramus is ventromedially projected. It contacts the quadrate and the prootic posteriorly and the pterygoid, the frontal and the postorbital dorsolaterally.

The foramen for $\mathrm{CN} \mathrm{V}$ is large and oval and almost equal in size (height and width) to the trigeminal groove. The laterosphenoid forms the anterodorsal margins of the foramen, whereas the prootic forms the posteroventral margins. Endocranially, the passage for all the branches of the trigeminal nerve is large in diameter, but short. Because of the fractures, it is possible to observe, in the lateral view of the braincase, the foramen for the tympanic branch of the trigeminal nerve, which separates posterodorsally (and passes through a foramen medially bounded by the prootic), entering the middle ear cavity (Fig. 5). The supraorbitary branch of the $\mathrm{CN} V$ leaves a vertical groove on the laterosphenoid, dorsal to the $\mathrm{CN} \mathrm{V}$ foramen, indicating its pathway. In turn, the ophthalmic branch $\left(\mathrm{CN} \mathrm{V}_{1}\right)$ leaves a horizontal groove anteriorly, whereas the mandibular and maxillary branches $\left(\mathrm{CN} \mathrm{V}_{2,3}\right)$ leave a wide groove ventral to the trigeminal recess (Fig. 5). Internally, the passage for all the branches of this nerve is large in diameter, but short, as seen in the endocast. None of the cranial nerves anterior to $\mathrm{CN} \mathrm{V}$ are preserved in MLP 68-IX-V-1.

The internal foramina of CN VI are observed on the floor of the endocranial cavity (MLP 68-IX-V-1) (Fig. 3A). The passages of this nerve are short and run anteroventrally, entering the pituitary fossa (Fig. 3B).

Cranial nerve CN VII leaves the endocranial cavity through a small foramen in the prootic, located just posterior to $\mathrm{CN}$ V. Its passage runs laterally into the middle ear cavity (Fig. 5). In G. gangeticus, there are two separate internal foramina for $\mathrm{CN}$ VII, indicating the endocranial separation of the palatine and hyomandibular branches of this nerve (Gold 2011, fig. 5). In complete crocodile skulls, the external foramen for CN VII is not observable in lateral view. However, in Gryposuchus neogaeus (MLP 73-IV-15-1), it is possible to observe this foramen, and the exit foramen of the tympanic branch of the trigeminal nerve, due to fractures on the right side of the braincase (Fig. 5).

Although the sediment was removed from the endocranial cavity of MLP 68-IX-V-1, CN VIII cannot be identified, since 


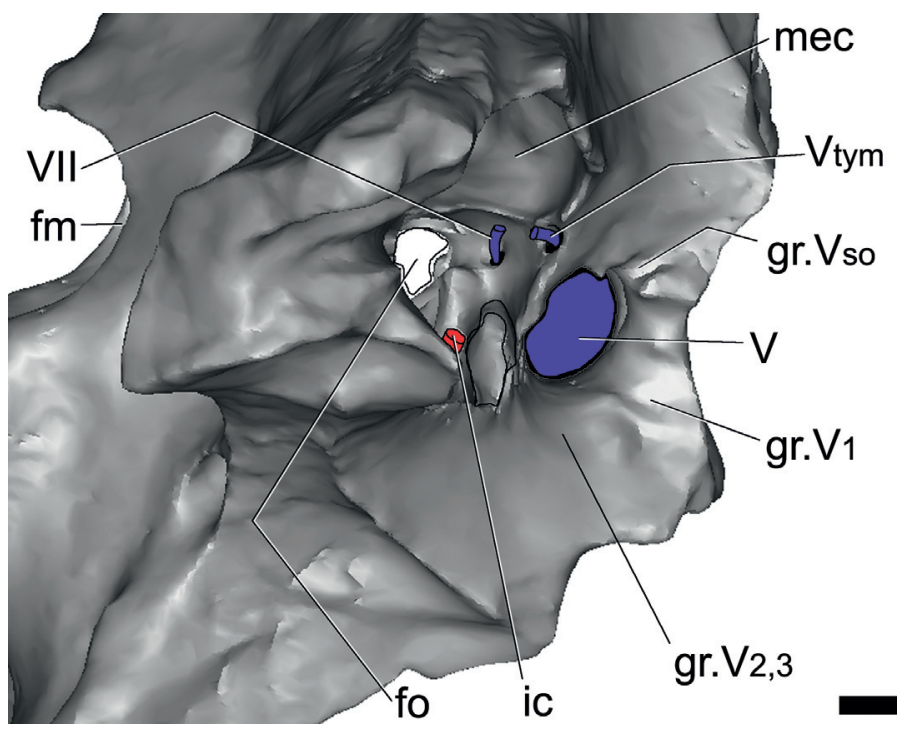

Figure 5 Gryposuchus neogaeus, MLP 68-IX-V-1: digital reconstruction of the braincase; detail of the middle ear cavity and associate cranial foramina. Abbreviations: $\mathrm{fm}=$ foramen magnum; fo $=$ unosssified area corresponding to the fenestra ovalis; gr. $\mathrm{V}_{1}=$ groove left by the ophthalmic branch of the trigeminal foramen; gr. $\mathrm{V}_{2}=$ groove left by the maxillary branch of the trigeminal foramen; gr. $\mathrm{V}_{3}=$ groove left by mandibular branch of $\mathrm{CN} \mathrm{V}$; gr. $\mathrm{V}_{\mathrm{so}}=$ groove left by supraorbital branch of $\mathrm{CN} \mathrm{V}$; ic = internal carotid artery; mec $=$ middle ear cavity; $\mathrm{V}_{\mathrm{tym}}=$ tympanic branch of $\mathrm{CN} \mathrm{V}$ that enters the middle ear cavity; $\mathrm{V}, \mathrm{VII}=$ cranial nerves $(\mathrm{CN})$. Scale bar $=10 \mathrm{~mm}$.
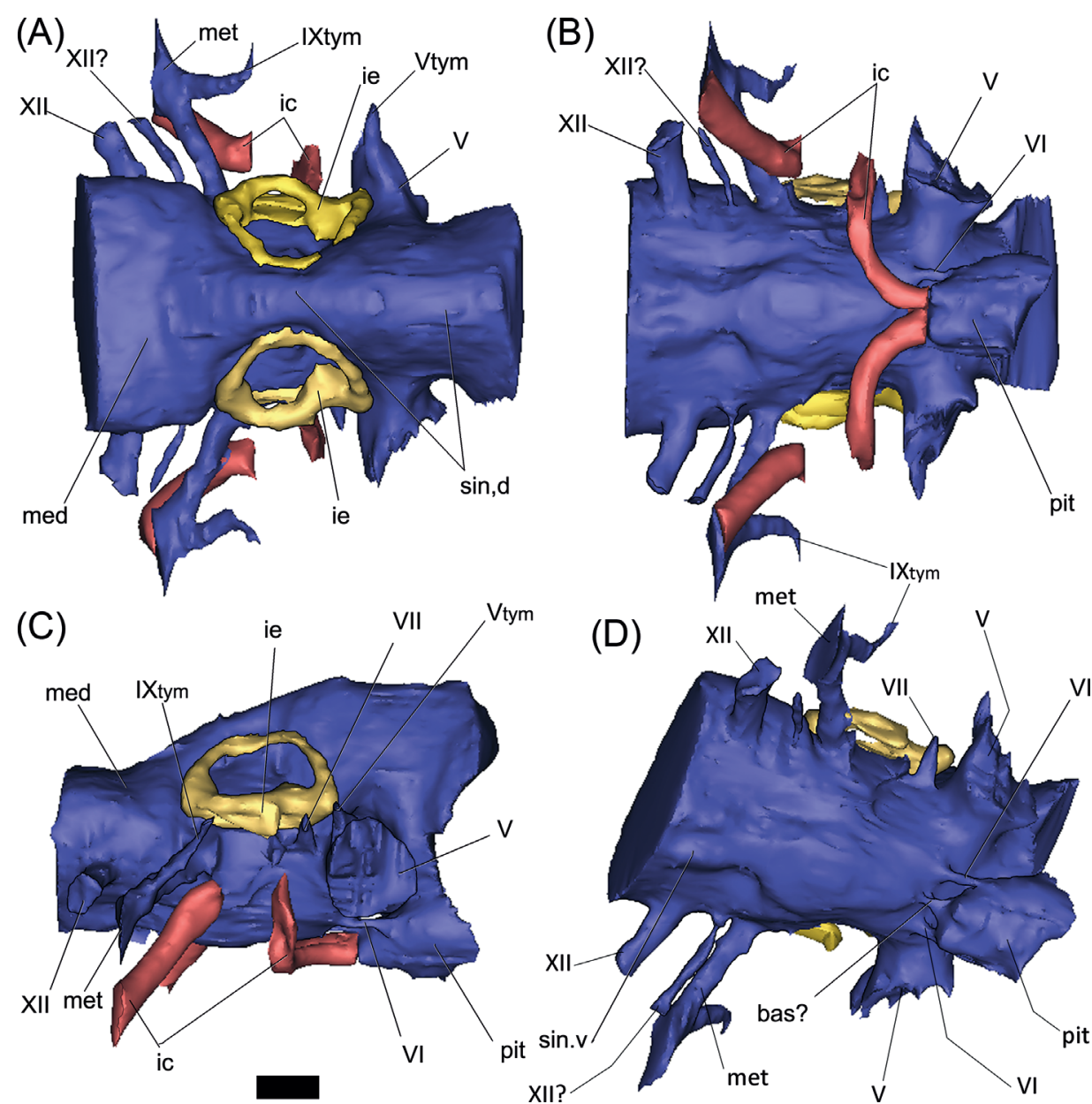

Figure 6 Gryposuchus neogaeus, MLP 68-IX-V-1: digital reconstruction of the cranial endocast, inner ear and internal carotid arteries in dorsal (A), ventral (B), right lateral (C) and posterolateroventral (D) views. Abbreviations: bas? = basilar artery; ic $=$ internal carotid artery; ie = inner ear; med = medulla oblongata; met $=$ metotic passage for CN IX-XI; pit = pituitary; sin.d $=$ dorsal longitudinal venous sinus; $\sin . \mathrm{v}=$ ventral longitudinal venous sinus; $\mathrm{V}_{\mathrm{tym}}=$ tympanic branch of $\mathrm{CN} \mathrm{V}$ that enters the middle ear cavity; $\mathrm{IX}_{\mathrm{tym}}=$ tympanic branch of CN IX separated from the metotic passage that enters the middle ear cavity; V, VI, VII, XII = cranial nerves $(\mathrm{CN})$. Scale bar $=10 \mathrm{~mm}$. 
(A)

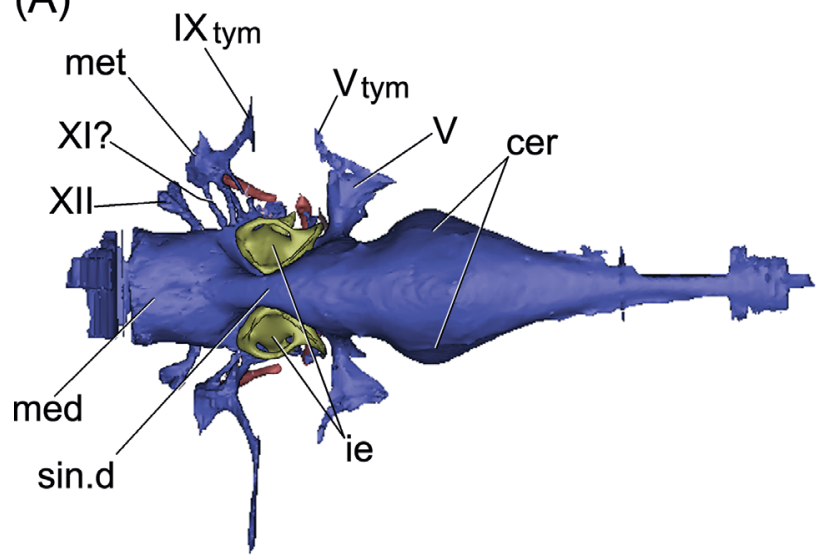

(C)

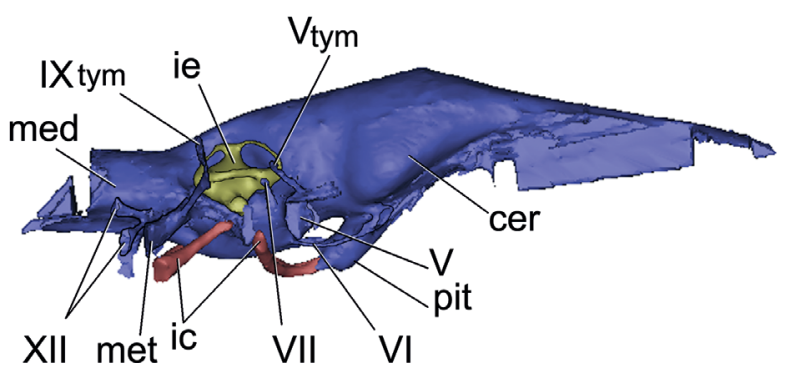

(B)

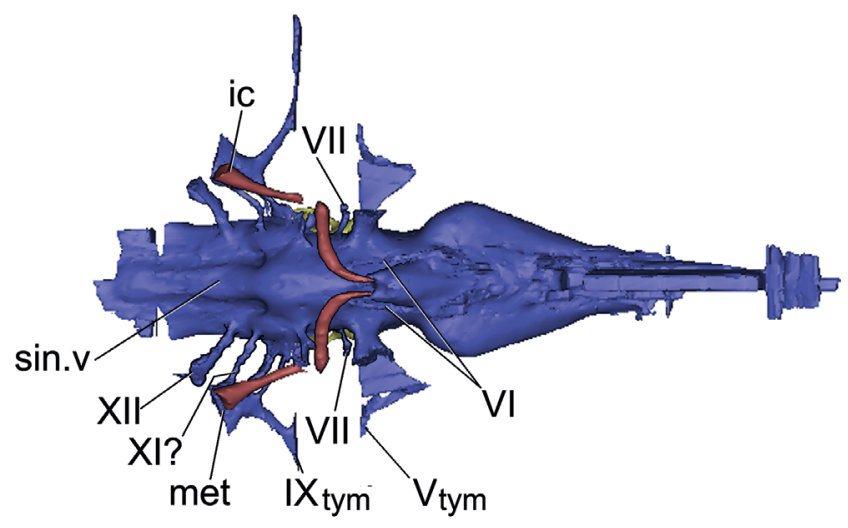

(D)

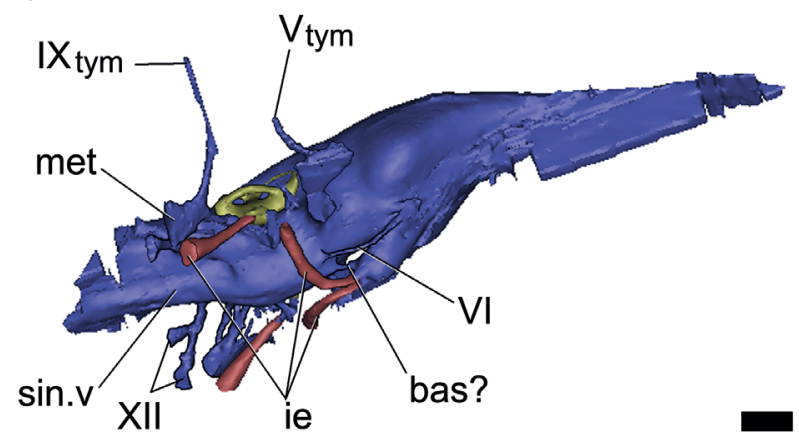

Figure 7 Gavialis gangeticus, MLP 602: digital reconstruction of the cranial endocast, inner ear and internal carotid arteries in dorsal (A), ventral (B), right lateral (C) and posterolateroventral (D) views. Abbreviations: bas? = basilar artery; cer = cerebral hemisphere; ic = internal carotid artery; ie = inner ear; med = medulla oblongata; met = metotic passage for CN IX-XI; pit = pituitary; sin.d = dorsal longitudinal venous sinus; $\sin . \mathrm{V}=$ ventral longitudinal venous sinus; $\mathrm{V}_{\text {tym }}=$ tympanic branch of $\mathrm{CN} \mathrm{V}$ that enters the middle ear cavity; $\mathrm{IX}_{\mathrm{tym}}=$ tympanic branch of CN IX separated from the metotic passage that enters the middle ear cavity; V, VI, VII, XI, XII $=$ cranial nerves $(\mathrm{CN})$. Scale bar $=10 \mathrm{~mm}$.

the vestibular eminence (medial wall of the otic capsule) on each side is not preserved. It probably remained cartilaginous in the adult specimen (Fig. 5).

\subsection{Cranial endocast and inner ear}

The specimen MLP 68-IX-5-1 is lacking the frontals, and therefore the forebrain is not reconstructed in the endocast (Figs 6,9). The endocast is relatively sub-horizontal and the angle formed between the mid-brain and the hindbrain is well marked on the dorsal margin of the endocast, suggesting a sigmoidal shape in lateral view (Fig. 6A). When compared with Gavialis gangeticus, the dorsal margin of the endocast (in lateral view) shows that the midbrain is relatively shorter in Gryposuchus neogaeus (Figs 6A, 7). The endocast of Thoracosaurus, in turn, is more sub-horizontal and shows poorly marked angles between the hindbrain, midbrain and forebrain (Lemoine, 1883, pl. 4, fig. 7).

The hindbrain of MLP 68-IX-5-1 is well preserved. There is no impression of the floccular recess on the preserved section of the prootic, as in other crocodiles; however, the incompleteness of the anterior wall of the vestibular eminence prevents any more conclusive assessment (see discussion below). The medulla oblongata is relatively shorter and wider than in the extinct Thoracosaurus and the extant Gavialis (Figs 6, 7). Endocranially, behind the dorsum sellae, the floor of the endocranial cavity has three small foramina, near the midline (Fig. 3A). The two lateral foramina correspond to the internal foramina of CN VI; for which the canals run anteroventrally, describing an arc and separately penetrating the pituitary fossa (Fig. 6D). The third median foramen leads into a passage of small diameter which runs anteroventrally across the basisphenoid to penetrate the pituitary fossa, identified here as the basilar artery canal (Figs 4A, 6D). This passage is present in the extant Gavialis (Fig. 7D), but is absent in other extant crocodiles, suggesting it is a feature particular to Gavialoidea. The basilar artery canal has been described in other archosaurs, such as some sauropodomorph dinosaurs (e.g., Galton 1985; Knoll et al. 2012; Paulina Carabajal 2012).

In the basicranium, the pituitary fossa is well developed and, if compared with Caiman, it is relatively larger, as in the extinct Thoracosaurus (Lemoine 1883, pl. 4, figs 6, 7) and the extant Gavialis (Figs. 3B, 6C, 7C). As shown in the endocast, the pituitary of Gryposuchus is dorsoventrally depressed and posteroventrally projected at a low angle (Fig. 6C). The internal carotid arteries enter the distal end of the pituitary fossa through separated canals ventrally to the median passage, identified as the basilar artery (Fig. 6B, D). The passages for the internal carotid arteries are large (three times the diameter of $\mathrm{CN}$ VI) and are not completely enclosed in bone. Therefore, the cast of each passage is missing a short section ventrally to the inner ear, as in Gavialis gangeticus (Figs 6C, 7C). This section corresponds to the middle ear cavity (when the internal carotid enters the middle ear, the canal is not enclosed by bone).

In the posteroventral section of the medulla oblongata, there are two passages of small diameter. The posterior-most one corresponds to CN XII; whereas the anterior and smaller one is located closer to the metotic passage, though it is not possible to determine if it corresponds to a separate branch of CN XII, or to a separate CN XI. In the endocast of Gavialis gangeticus, however, there are two passages for CN XII, one 

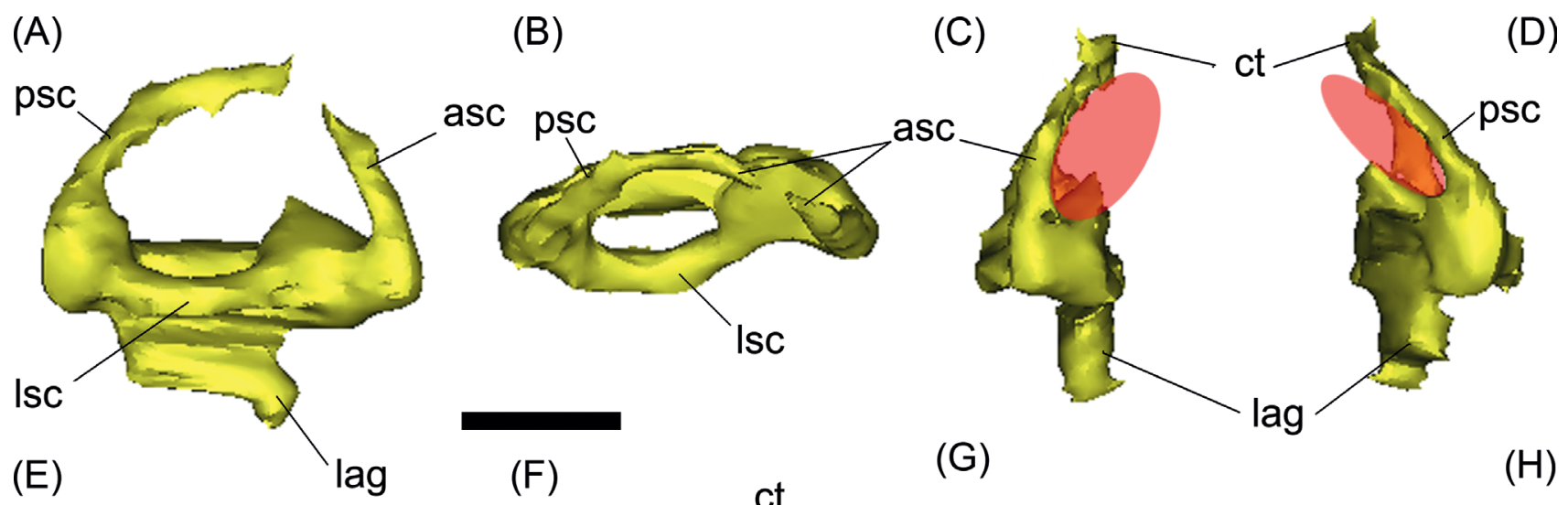

$(\mathrm{E})$

lag

$(\mathrm{F})$

(G)

$(\mathrm{H})$
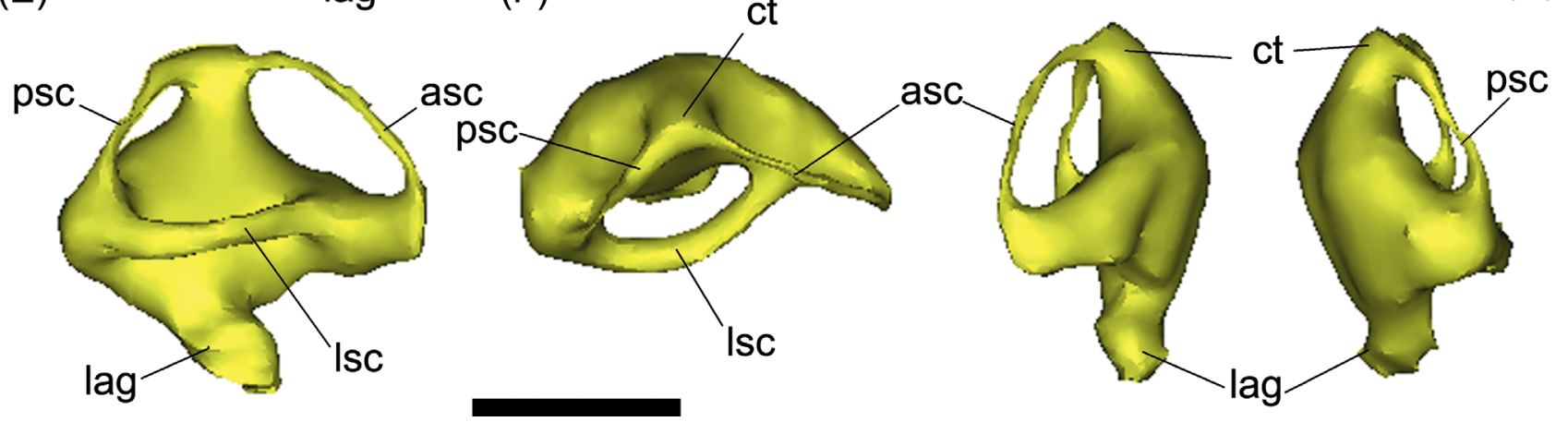

Figure 8 (A-C) Gryposuchus neogaeus, MLP 68-IX-V-1: digital reconstruction of right inner ear in lateral (A), dorsal (B) and anterior (C) views. (E-G) Gavialis gangeticus, MLP 602: digital reconstruction of right inner ear in lateral (E), dorsal (F) and anterior $(\mathrm{G})$ views. Abbreviations: asc $=$ anterior semicircular canal; $\mathrm{ct}=$ common trunk; lag = lagena; lsc = lateral semicircular canal; $\mathrm{psc}=$ posterior semicircular canal. Scale bars $=10 \mathrm{~mm}$.

dorsal to the other. The metotic passage (for CN IX-XI) is larger in diameter and runs laterally from the endocast. Distally, the metotic passage has a bifurcation and the resulting smaller passage runs anterodorsally, entering the middle ear cavity posteriorly. This passage probably corresponds to the tympanic branch of the glossopharyngeal nerve (Figs 5, 6A, 9B), which is also observed in the extant Gavialis (Fig. 7). On the ventral side of the medulla oblongata, there is a wellmarked ventral venous sinus (Fig. 6B, D).

Cranial nerve VII has a small passage, located posterior to CN V (Fig. 6C). It projects shortly laterally, before entering the medial sector of the middle ear cavity (Fig. 5), as in Gavialis gangeticus.

The passage of CN VI has a small diameter. It is short and runs anteroventrally from the medulla oblongata, forming an arc and entering the pituitary fossa posteriorly (Fig. 6C, D). In Gavialis gangeticus, CN VI runs anteriorly, forming an arc and exiting the braincase through an eye-shaped foramen, through which $\mathrm{CN}$ III and CN IV would also be exiting the endocranial cavity. The relationship between CN VI and the pituitary is a difference between the fossil and the extant species (entering the pituitary fossa in Gryposuchus but not in Gavialis).

The passage of $\mathrm{CN} \mathrm{V}$ has the largest diameter in the endocast. It is laterally projected from the endocast (Fig. 6) and exits the braincase through a large subcircular foramen (Figs $3 \mathrm{D}, 4)$. The diameter of the base of the root of the trigeminal nerve in Gryposuchus neogaeus is relatively more than $50 \%$ larger than in the extant Gavialis (Fig. 7). The cast of the trigeminal passage includes (distally) the small passage for the tympanic branch, which enters the middle ear cavity. Cranial nerves anterior to $\mathrm{CN} \mathrm{V}$ are not preserved in MLP 68-IX-5-1 and they are not distinguished in MLP 26-413.

2.2.1. Blood vessels. In both extinct and extant gavialoids species, the internal carotid artery shows the same path pattern
(Figs 6, 7). It enters the braincase through a large foramen lateroventrally to CN XII. The passage is large in diameter in Gryposuchus neogaeus and is reconstructed in two sections. The posterior section of the carotid artery runs anterodorsally to enter the middle ear cavity (just below the inner ear) (Figs 5, $6 \mathrm{~B}, \mathrm{C})$. Here, the passage is no longer enclosed in bone and its path is missing between $\mathrm{CN}$ VIII and CN IX-XI. The anterior section of the internal carotid canal continues lateromedially and then forms a loop, turning ventromedially to run shortly anteriorly to enter the pituitary fossa (Fig. 6B, C).

The dorsal longitudinal venous sinus (see Witmer et al. 2008) is well developed, obscuring the dorsal morphology of the soft tissues of the brain in the endocast (Fig. 6A). There is no caudal middle cerebral vein. The ventral longitudinal venous sinus in Gryposuchus neogaeus, Gavialis gangeticus and Thoracosaurus (Lemoine 1883, pl. 4, fig. 6) is well developed and shows the same morphological pattern, being drop-shaped just posterior to the pituitary (Figs 6B, 7B). However, whereas the medullar expansion is rounded in Gryposuchus, it has parallel borders in Thoracosaurus and in the extant Gavialis, where it is also relatively longer, since the floor of the medulla oblongata extends posteriorly to CN XII (Fig. 7).

2.2.2. Inner ear. The inner ear of Gryposuchus neogaeus is partially preserved, including the labyrinth and the vestibular section (Figs 6, 8A-D). In both sides, the medial part of the labyrinth, particularly the common trunk and the medial portions of the anterior and posterior semicircular canals, are missing, since the walls of the vestibular eminence are not preserved. As mentioned, it is not possible to conclude if this is result of symmetrical fractures, or because the walls reminded unossified in the adult (Figs 3A, B, 5). In Gavialis gangeticus, the ossified vestibular eminence wall is markedly thin and the labyrinth is completely reconstructed, suggesting these are poorly ossified in adult gavialoids in general. In Gryposuchus 


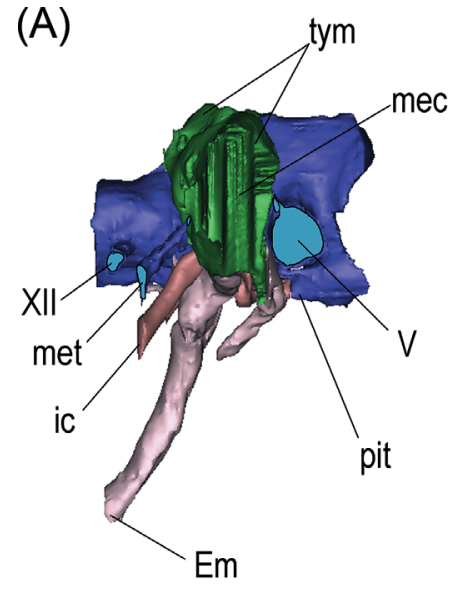

(D)

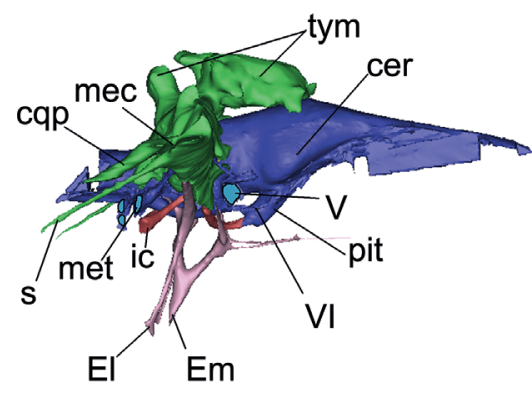

(B)

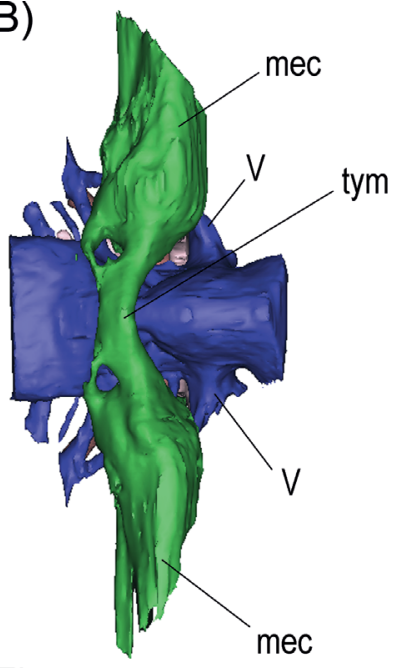

(E)

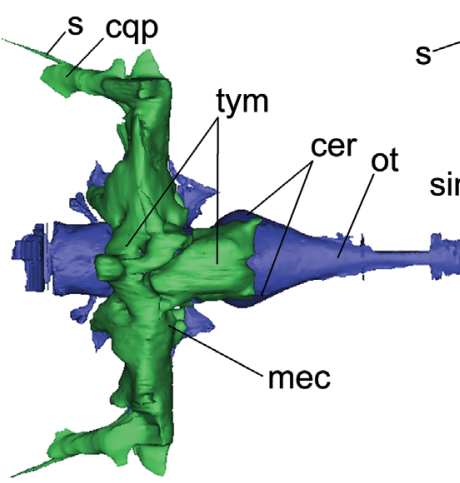

(C)

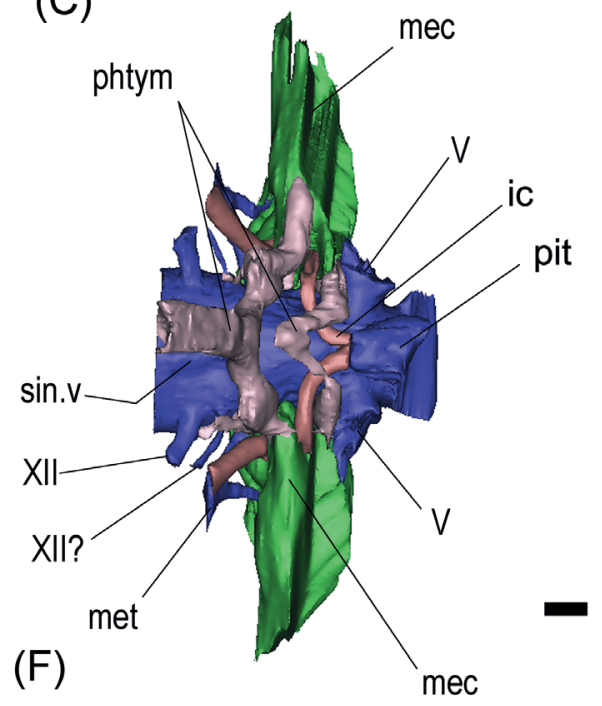

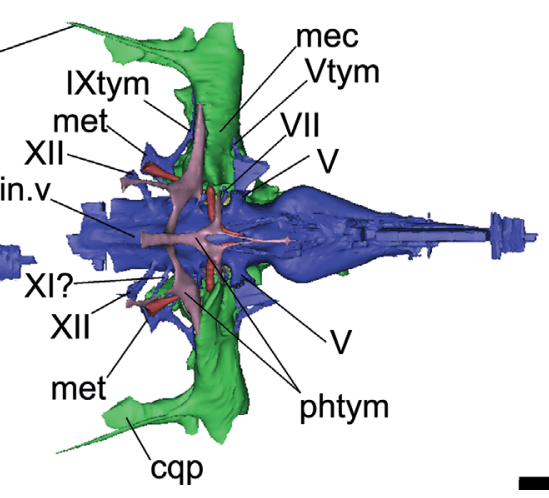

Figure 9 (A-C) Gryposuchus neogaeus, MLP 68-IX-V-1: digital reconstruction of cranial endocast and pneumatic recesses in right lateral (A), dorsal (B) and ventral (C) views. (E-G) Gavialis gangeticus, MLP 602: digital reconstruction of cranial endocast and pneumatic recesses in right lateral (D), dorsal (E) and ventral (F) views. Abbreviations: cer $=$ cerebral hemisphere; cqp $=$ cranio quadrate passage; $\mathrm{El}=$ Eustachian lateral passages; $\mathrm{Em}=$ Eutachian middle foramen and passage; $\mathrm{ic}=$ internal carotid artery; mec = middle ear cavity; met $=$ metotic passage for CN IX-XI; ot = olfactory tract; phtym = pharyngotympanic passages; pit = pituitary; $\mathrm{s}=$ siphonium passage; $\sin . \mathrm{v}=$ ventral longitudinal venous sinus; $\mathrm{tym}=$ paratympanic dorsal recess; $\mathrm{V}_{\mathrm{tym}}=$ tympanic branch of $\mathrm{CN} \mathrm{V}$ that enters the middle ear cavity; $\mathrm{IX}_{\mathrm{tym}}=$ tympanic branch of $\mathrm{CN}$ IX separated from the metotic passage that enters the middle ear cavity; V, VI, VII, XI?, XII = cranial nerves $(\mathrm{CN})$. Scale bars $=10 \mathrm{~mm}$.

neogaeus, the reconstruction of the anterior semicircular canal is oval-shaped and larger than the posterior semicircular canal, which is in turn markedly larger than the lateral semicircular canal (Fig. 8B-D). This pattern is the same in the extant Gavialis (Fig. 8E-H), although in Gryposuchus neogaeus, the semicircular canals are more elliptical (compressed) than in Gavialis (Fig. 8). In both species, the angle formed between the anterior and posterior semicircular canals is approximately $90^{\circ}$, as in other crocodylians such as caimans and crocodylids (e.g., Bona \& Paulina Carabajal 2013).

In Gryposuchus neogaeus and Gavialis gangeticus, the lagenar section of the inner ear is not well developed in length (Fig. 8), suggesting that this part was extremely reduced (see discussion below).

\subsection{Braincase pneumaticity and eustachian system}

Three different pneumatic areas can be recognised in the endocast models of Gryposuchus and Gavialis: the dorsal paratympanic recess; the middle ear sinus system; and the pharyngotympanic system (see Witmer \& Ridgely 2008; Dufeau 2011) (Fig. 9).

2.3.1. Dorsal paratympanic recess. This recess is developed dorsal to the cranial endocast, affecting only the parietal internally (Fig. 3G). Lateroventrally, this pneumatic cavity is con- tinuous with the middle ear cavity (Fig. 9A). In dorsal view, this recess is transversely developed as an anteroposteriorly narrow cavity (Fig. 9B). It is located just dorsal to the inner ear level and expands slightly distally where it merges with the middle ear cavity or recess. In Gavialis gangeticus, on the contrary, this cavity affects both the supraoccipital and parietal, and is much more anteriorly developed, reaching the posterior section of the cerebral hemispheres (Fig. 9D, E).

2.3.2. Middle ear sinus system. This recess is laterally developed to the inner ear region, and merges dorsally with the paratympanic recess and ventrally with the pharyngotympanic recess (Fig. 9A-C). In Gryposuchus neogaeus, the distal expansion of this cavity is obscured by fractures. In ventral view, it is evident that it is also relatively less developed than in Gavialis gangeticus (Fig. 9C, F). In the latter species, a small canal the siphonium - runs posteriorly projected between the paroccipital process and the quadrate (almost fused, distally it is excavated on the quadrate only), to exit through a small foramen located in the distal medial end of the posterior side of the quadrate, close to the articular condyle (Fig. 9D-F). A more dorsal and lateral passage (also larger in diameter), passes parallel and dorsally to the siphonium passage, corresponding to the cranioquadrate passage for the stapedial artery and a branch of the facial nerve (Fig. 9D-F). 
2.3.3. Pharyngotympanic system. This is a ventral pneumatic system, comprising two primary inflations of evaginated pharyngeal epithelium: the pharyngotympanic sinus, which communicates with the pharynx via the lateral Eustachian tubes (and forms the cavum tympanicum proprium); and the median pharyngeal sinus, which communicates with the pharynx via the median pharyngeal tube (Dufeau 2011) (Fig. 9). In Gryposuchus neogaeus, the pharyngotympanic system is simple, conformed by two main sections (Fig. 9A, C). The principal section consists of a median subvertical tube (exiting ventrally through the median Eustachian foramen), dorsally bifurcated into two lateral dorsolaterally projected branches. Each of these lateral branches merges ventrally with the middle ear cavity of the same side (Fig. 9C, F). There are no passages running ventrally from the lateral branches, so externally in the braincase only the median Eustachian tube foramen is observed. The second section is a V-shaped cavity anterior and parallel to the main Eustachian tubes (Fig. 9A, C). The dorsal branches merge also with the middle ear cavity, but more anteriorly, just below the root of $\mathrm{CN} \mathrm{V} \mathrm{(Fig.} \mathrm{9C).}$ There is no visible contact between the anterior and posterior sections.

In Gavialis gangeticus, the median Eustachian tube is vertically oriented (Fig. 9D). It has a single passage running anterodorsally and bifurcates dorsally into two branches, each of which has a dorsal projection (that merges with the middle ear cavity) and a ventral projection (a canal that exits lateral to the median Eustachian foramen) (Fig. 9D, F). In Gryposuchus neogaeus, the median anteriorly projected passage merges with the V-shaped passages located anteriorly (Fig. 9A). Only the median canal is developed, and the lateroventral canals are missing or are extremely thin, since they are not recognisable in the CT scans.

\section{Discussion}

A description of the general morphology of the skull of Gryposuchus neogaeus (= Rhamphostomopsis neogaeus; Burmeister 1885; Rusconi 1933) was originally provided by Gasparini (1968). Based mostly on specimen MLP 26-413 (Gasparini 1968, fig. 1), she described the overall morphology of several preserved skull bones (premaxillae, maxillae, nasals, squamosals, postorbitals, quadrate, quadratojugal and mandible (Gasparini 1968, pp 301-303), but did not describe the braincase in detail. However, in the original diagnosis (Gasparini 1968, p. 300), she remarked on a supratemporal fenestra bigger than the orbits (a feature shared with G. croizati, and Gryposuchus sp.) and a slender post-temporal bar. Although a systematic revision and a phylogenetic relationships of G. neogaeus is in process by Bona et al., there are already several braincase features that allow us to differentiate this species from other Gryposuchus, such as a narrowed post-temporal bar with parietals tapering laterally and a relatively developed supraocciptal knob. As described above, in G. neogaeus, the parietal presents a medial notch which articulates with the supraoccipital oblique process; this condition is present in other Gryposuchus (e.g., Gryposuchus sp.) and absent in basal forms such as Eothoracosaurus mississippiensis (Brochu 2004).

Observing and comparing the internal braincase anatomy of extinct and extant gavialoids, there are two structures that deserve consideration: the floccular recess and the basilar artery canal. As mentioned above, the basilar artery canal is a median passage for this vessel at the floor of the cerebral cavity (basisphenoid) that enters the pituitary fossa. This canal is absent in post-hatching individuals of extant crocodylians such as Caiman, Alligator and Crocodylus, and is probably closed during ontogeny. In Gryposuchus neogaeus and the extant Gavialis, this canal remains open in adult stages, suggesting that its presence could be a trait of Gavialoidea. The relationship between this passage and the supply of the pituitary during ontogeny in crocodylians is unclear.

The flocculus is a paired cerebellar structure associated with the occulomotor reflex, which integrates the movement of the neck, eyes and balance organs (Witmer et al. 2003). It is situated laterally to the cerebellar corpus and, when it is developed, the flocculus is housed in a recess on the anterior side of the medular eminence. Historically, the flocculus has been related to bipedalism and flying capabilities within Archosauria, given its great development in birds and pterosaurs (Witmer et al. 2003); although recently it has been regarded as a centre of gaze stabilisation (Walsh et al. 2013). The floccular recess is distinguishable in several terrestrial forms of pseudosuchians, but is extremely reduced, or even absent, in neosuchians such as Metriorhynchus, Crocodylus and Caiman, probably suggesting that the reduction of the flocculus is a derived condition related to aquatic environments (von Baczko et al. 2015). Both extinct and extant species of gavialoids show this condition.

In relation to superficial vasculature, potential roles for vascularised tissues on the skull roof could be related to a thermoregulatory adaptation, given that the tempororbital vessels communicate with the encephalic vessels and ophthalmic rete (Holliday \& Gardner 2012; Bona et al. 2013). In gavialoids, these vessels are more internal than in amphibian alligatorids (e.g., Mourasuchus, Caiman). This is also true for aquatic forms such as marine neosuchians (e.g., metriorhynchids), in which the skull roof is convergently reduced. However, the hypothesis that this change of disposition of superficial vasculature in the skull table is linked with more or less aquatic habits must be contrasted with more morphological evidence. As stated above, in Gryposuchus neogaeus and Gavialis gangeticus, the lagenar section of the inner ear was reduced in comparison with the extinct Mourasuchus (Bona et al. 2013, fig. 5E); Caiman (Walsh et al. 2009, fig. 1b) and Crocodylus (Witmer et al. 2008). Since the length of the lagena is directly related to the hearing capabilities (e.g., Walsh et al. 2009), the consequence for hearing in extant and extinct gavialids suggests a decrease in the capture of sound capabilities in relation with more terrestrial forms, characteristically present since the Miocene.

Both specimens of Gryposuchus neogaeus come from a level informally called "Conglomerado Osífero", which is a Miocene fluvial deposit that also concentrated skeletal fragments of several species of alligatorids, with different ecological requirements, which probably came from an ancient broad geographic area. Given the completeness of the preserved specimens, only G. neogaeus appears to be an autochthonous inhabitant of the ancient "Paraná River", and was probably a more aquatic form (Bona et al. 2013). Extant gavialids are highly aquatic, piscivorous crocodiles and they have reduced skull pneumaticity relative to other crocodiles. Dufeau (2011) stated that this is the result of two situations: (1) in the braincase of piscivorous taxa, the potential of being pneumatised by diverticula is constrained because of the increment of jaw adductor mass musculature (which requires a greater muscle attachment area on the braincase) that result in narrower braincases; and (2) underwater feeders show reduction of pneumaticity compared to other crocodiles (e.g., Paleosuchus) in terms of air-filled bones/ buoyancy relation. As in extant gavialids, Gryposuchus neogaeus shows even more reduced skull pneumaticity than in the extant Gavialis, suggesting that the Miocene taxon was already anatomically prepared for underwater feeding. 


\section{Conclusion}

The knowledge of the detailed morphology of the braincase and its variation is a key to understanding the systematic and phylogenetic relationships of gavialoids. Gryposuchus neogaeus shares several braincase features with other Gryposuchus species (see description above) and even with extant forms. Particularly interesting is the presence of the passage identified as the basilar artery canal in the basicranium in adult forms of Gryposuchus neogaeus and Gavialis gangeticus, but not in other crocodylians, suggesting a potential synapomorphy of Gavialoidea. The neuroanatomy of extinct and extant species (including encephalic, inner ear and braincase pneumaticity) responds to the same general morphological pattern established in the group at least since the Miocene. However, there are some differences: the cranial endocast of Gryposuchus neogaeus has a relatively shorter and robust medulla oblongata than that in the extant Gavialis and, in addition, the trigeminal passage is more than $50 \%$ larger. In turn, the paratympanic pneumaticity is reduced as compared to the extant form.

When comparing the endocast of both extinct and extant gavialoid species, several pieces of morphological evidence arise in relation to its aquatic habits and the way of feeding of these animals: the inner shows a reduced lagena, meaning low hearing capabilities compared with other amphibious extant crocodiles; the cerebellar flocculus is reduced, as in other aquatic neosuchuians; and the skull pneumaticity is reduced (especially in the skull roof and in the basicranium), probably related to a subaquatic behaviour. In this sense, the main goal of this contribution is to describe in detail, and compare for the first time, the external and internal neurocranial morphology of an extinct gavialoid (i.e., G. neogaeus), in order to yield new evidence to explore its implication for the palaeobiology of the group.

\section{Acknowledgements}

We are grateful to Dr. Sergio Vizcaíno for the invitation to participate in this Special Issue on 'Form, Function and Palaeobiology'. We also thank Marcelo Reguero and Jorge Williams (MLP) for allowing us to CT scan and study the materials under his care; and Rafael Souza (Museu Nacional, UFRJ) for his comments and for allowing the study of fossil material under his care. We are also grateful to the technical staff of the Hospital San Juan de Dios, Argentina for realising the CT scans. We would like to thank Eugenia Gold and an anonymous reviewer for their comments and observations, which improved this manuscript. This study was partially financed by the Agencia Nacional de Promoción Científica y Tecnológica PICT 2008/0261 (to ZG), PICT 2012/1425 (to APC) and by the Universidad Nacional de La Plata UNLP 11/N 749 (to MS Fernández)

\section{References}

Benton, M. J. \& Clark, J. M. 1988. Archosaur phylogeny and the relationships of the Crocodylia. In Benton, M. (ed.) The Phylogeny and Classification of Tetrapods: Volume 1: Amphibians, Reptiles, Birds. The Systematics Association Special Volume 35, 295-338. Oxford: Oxford University Press. 392 pp.

Bona, P., Degrange, F. J. \& Fernández, M. S. 2013. Skull anatomy of the bizarre crocodylian Mourasuchus nativus (Alligatoridae, Caimaninae). The Anatomical Record 296, 227-39.

Bona, P. \& Paulina Carabajal, A. 2013. Caiman gasparinae sp. nov., a huge alligatorid (Caimaninae) from the late Miocene of Paraná, Argentina. Alcheringa 37, 1-12.

Brandoni, D. \& Scillato-Yané, G. J. 2007. Los Megatheriinae (Xenarthra, Tardigrada) del Terciario de Entre Ríos, Argentina: aspectos taxonómicos y sistemáticos. Ameghiniana 44, 427-34.
Brochu, C. A. 2004. A new Late Cretaceous gavialoid crocodylian from eastern North America and the phylogenetic relationships of thoracosaurs. Journal of Vertebrate Paleontology 24, 610-33.

Burmeister, G. 1885. Examen crítico de los mamíferos y reptiles fósiles denominados por Don Augusto Bravard y mencionados en su obra precedente. Annales del Museo Nacional de Buenos Aires 3 , 95-173.

Cleuren, J. \& De Vree, F. 2000. Feeding in crocodylians. In Schwenk, K. (ed.) Feeding: Form, Function and Evolution in Tetrapod Vertebrates, 337-58. San Diego, CA: Academic Press. 564 pp.

Dufeau, D. L. 2011. The evolution of cranial pneumaticity in Archosauria: Patterns of paratympanic sinus development. Unpublished $\mathrm{PhD}$ Thesis, Faculty of the College of Arts and Sciences of Ohio University, USA. 175 pp.

Franzosa, J. W. 2004. Evolution of the brain in Theropoda (Dinosauria). Unpublished PhD Thesis, Faculty of the Graduate School of The University of Texas at Austin, USA. 357 pp.

Galton, P. M. 1985. Cranial anatomy of the prosauropod dinosaur Plateosaurus from the Knollenmergel (Middle Keuper, Upper Triassic) of Germany. II. All the cranial material and details of soft-part anatomy. Geologica et Palaeontologica 19, 119-59.

Gasparini, Z. 1968. Nuevos restos de Rhamphostomopsis neogeaeus (Burm.) Rusconi, 1933, (Reptilia, Crocodilia) del "Mesopotamiense" (Plioceno medio-superior) de Argentina. Ameghiniana 5, 299-311.

Gold, M. E. L. 2011. Cranial osteology and braincase morphometrics of Gavialis gangeticus: implications for crocodilian phylogenetics. Master's Thesis, University of Iowa, USA. http://ir.uiowa.edu/ etd/2504.

Gürich, G. 1912. Gryposuchus jessei ein neues schamalschnauziges Krokodile aus den jüengeren Ablagerungen des oberen AmazonasGabietes. Mitteilungen des Mineralogischen, Geologischen Instituts Hamburg 4, 59-71.

Holliday, C. M. \& Gardner, N. M. 2012. A new eusuchian crocodyliform with novel cranial integument and its significance for the origin and evolution of Crocodylia. PLOS ONE 7, e30471. doi: 10.1371/journal.pone.0030471

Holliday, C. M. \& Witmer, L. C. 2004. Anatomical domains within the heads of archosaurs and their relevance for functional interpretation. Journal of Vertebrate Paleontology 24(suppl. 3), 71.

Holliday, C. M. \& Witmer, L. M. 2009. The epipterygoid of crocodyliforms and its significance for the evolution of the orbitotemporal region of eusuchians. Journal of Vertebrate Paleontology 29, 715-33.

Hopson, J. A. 1979. Paleoneurology. In Gans, C., Northcutt, R. G. \& Ulinski, P. (eds) Biology of the Reptilia, Volume. 9: Neurology A, 39-146. New York: Academic Press. xv + 462 pp.

Jerison, H. J. 1973. Evolution of the brain and intelligence. New York \& London: Academic Press. 483 pp.

Kawabe, S., Shimokawa, T., Miki, H., Okamoto, T. \& Matsuda, S. 2009. A simple and accurate method for estimating the brain volume of birds: possible application in paleoneurology. Brain Behavior and Evolution 74, 295-301.

Knoll, F., Witmer, L.M., Ortega, F., Ridgely, R. C. \& SchwarzWings, D. 2012. The braincase of the basal sauropod dinosaur Spinophorosaurus and 3D reconstructions of the cranial endocast and inner ear. PlosOne 7, e30060. doi:10.1371/journal.pone.0030060

Knoll, F., Witmer, L. M., Ridgely, R. C., Ortega, F. \& Sanz, J. L. 2015. A new titanosaurian braincase from the Cretaceous "Lo Hueco" locality in Spain sheds light on neuroanatomical evolution within Titanosauria. PLOS ONE 10(10), e0138233. doi:10.1371/ journal.pone.0138233.

Langston, W. Jr. 1965. Fossil crocodilians from Colombia and the Cenozoic history of the Crocodilia in South America. University of California Publications in Geological Sciences 52, 1-15.

Langston, W. Jr. \& Gasparini, Z. 1997. Crocodilians, Gryposuchus and the South Americans gavials. In Kay, R. F., Madden, N. H., Ciffelli, R. L. \& Flinn, J. J. (eds) Vertebrate paleontology in the Neotropics: The Miocene fauna of La Venta, Colombia, 113 54. Washington DC: Smithsonian Institution.

Lemoine, V. 1883. Note sur l'encéphale du Gavial du Mont-Aimé, étudié sur trois moulages naturels. Bulletin de la Société Géologique de France 3, 158-62.

Paulina Carabajal, A. 2012. Neuroanatomy of titanosaurid dinosaurs from the Upper Cretaceous of Patagonia, with comments on endocranial variability within Sauropoda. The Anatomical Record 295, 2141-56.

Paulina Carabajal, A., Carballido J. \& Currie, P. J. 2014. Braincase, neuroanatomy and neck posture of Amargasaurus cazaui (Sauropoda: Dicraeosauridae) and its implications for understanding head posture in sauropods. Journal of Vertebrate Paleontology 34, $870-82$ 
Riff, D., Romano, P. S. R., Oliveira, G. R \& Aguilera O. A. 2010. Neogene crocodile and turtle fauna in Northern South America. In Hoorn, C. \& Wesselingh, F. (eds) Amazonia, Landscape and Species Evolution: a Look into the Past, 259-80. Oxford: WileyBlackwell. 464 pp.

Riff, D. \& Aguilera O. A. 2008. The world's largest gharials Gryposuchus: description of G. croizati n. sp. (Crocodylia, Gavialidae) from the Upper Miocene Urumaco Formation, Venezuela. Paläontologische Zeitschrift 82, 178-95.

Rusconi, C. 1933. Observaciones críticas sobre reptiles Terciarios de Paraná (Familia Alligatoridae). Revista de la Universidad Nacional de Córdoba 20, 1-52.

Salas-Gismondi, R., Flynn, J. J., Baby, P., Tejada-Lara, J. V., Wesselingh, F. P. \& Antonie, P.-O. 2015. A Miocene hyper-diverse crocodylian community reveals peculiar trophic dynamics in proto-Amazonian mega-wetlands. Proceedings of the Royal Society $B$ 282, 20142490. http://dx.doi.org/10.1098/rspb.2014.2490

Sedlmayr, J. C. 2002. Anatomy, evolution and functional significance of cephalic vasculature in Archosauria. Unpublished PhD Thesis, Ohio University, USA. 398 pp.

Walsh, S. A., Barrett, P. M., Milner, A. C., Manley, G. \& Witmer, L. M. 2009. Inner ear anatomy is a proxy for deducing auditory capability and behaviour in reptiles and birds. Proceedings of the Royal Society B 276, 1355-60.

Walsh, S. A., Iwaniuk, A. N., Knoll, M. A., Bourdon, E., Barrett, P. M., Milner, A. C., Nudds, R. L., Abel, R. L. \& Dello Sterpaio, P. 2013. Avian cerebellar floccular fossa size is not a proxy for flying ability in birds. PLOSONE 8(6), e67176. doi:10.1371/journal. pone.0067176

Witmer, L. M., Chatterjee, S., Franzosa, J. \& Rowe, T. 2003. Neuroanatomy of flying reptiles and implications for flight, posture and behavior. Nature 425, 950-53.

Witmer, L. M., Ridgely, R. \& Dufeau, D. L. 2008. Using CT to peer into the past: 3D visualization of the brain and ear regions of birds, crocodiles and nonavian dinosaurs. In Endo, H, \& Frey, R. (eds) Anatomical Imaging: Towards a New Morphology, 6787. Tokyo: Springer. 146 pp.

Witmer, L. M., \& Ridgely, R. C. 2008. The paranasal air sinuses of predatory and armored dinosaurs (Archosauria: Theropoda and Ankylosauria) and their contribution to cephalic architecture. Anatomical Record 291, 1362-88.

Von Baczko, M. B., Barrios, F., Desojo, J. B., Paulina Carabajal, A. \& Bona, P. 2015. New insights on the development of the flocculus on pseudosuchia (archosauria). XXIX Jornadas Argentinas de Paleontología Vertebrados, Actas $\mathbf{8 2}$.

MS received 17 June 2015. Accepted for publication 2 October 2016. 